\title{
Palatal palsy in a case of lepromatous leprosy
}

\author{
K. PAVITHRAN* \\ Department of Dermatology and Venereology, Medical College \\ Hospital, Kottayam-686 008, India
}

Accepted for publication 10 March 1994

Summary A male patient with lepromatous leprosy developed nasal regurgitation of food due to palatal palsy during Type 2 reaction. Early high-dose administration of corticosteroid achieved a prompt therapeutic response and he completely recovered from palatal palsy. The associated lagophthalmos, foot drop and ulnar paralysis persisted.

\section{Introduction}

Mycobacterium leprae commonly affects the sensory fibres of the peripheral nerves, although motor fibres are often affected. The trigeminal and facial nerves are also commonly affected, but as the involvement of other cranial nerves is uncommon, ${ }^{1-6}$ we report a patient with lepromatous leprosy who developed a palatal palsy during Type 2 reaction.

\section{Case report}

A 45-year-old man (Figure 1) was diagnosed to have lepromatous leprosy on 3 March 1983 on clinical, bacteriological and histopathological features. His history and progress are summarized in Table 1.

\section{Discussion}

The central nervous system remains unaffected in leprosy, though the cranial nerves during a superficial course may be involved. In the patient reported here, two cranial nerves - the facial fibres of the cranial part of the eleventh nerve which travel in the

*Correspondence: Dr K. Pavithran, Medical College Hospital, Alappuzha-688 005, India. 


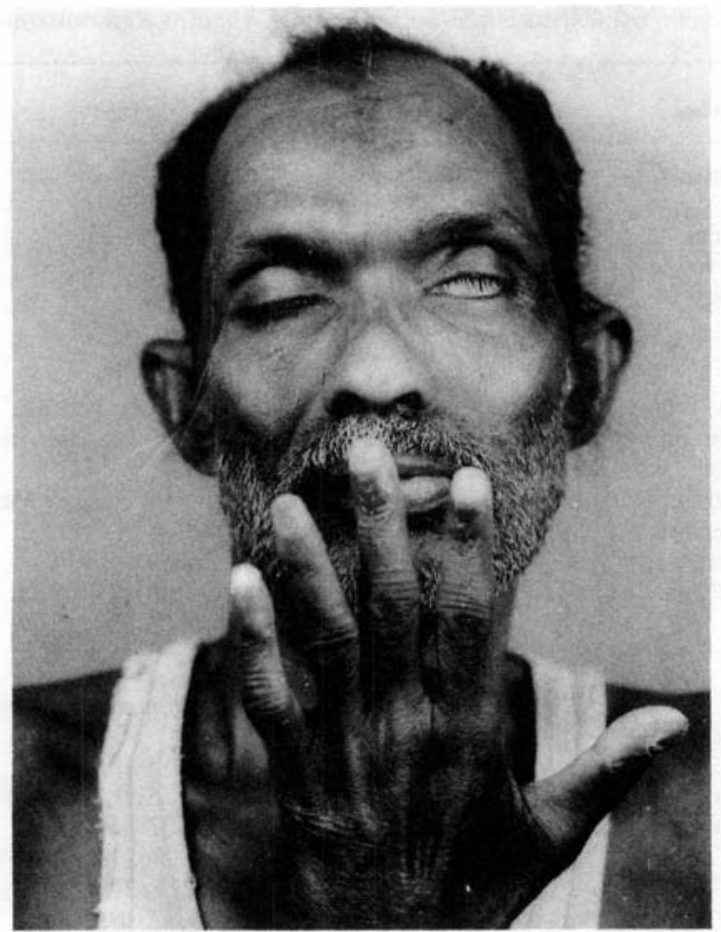

Figure 1. Note lagophthalmos of the left eye, the absence of nasolabial fold on the left side and clawing of the left hand.

vagus - were affected. Involvement of the zygomatic branch alone of the left facial nerve, resulting in lagophthalmos, and obliteration of the nasolabial fold suggested leprous aetiology for facial palsy in our patient. In most other conditions the facial nerve trunk, rather than its isolated branches, becomes affected, causing paralysis of all muscles of one-half of the face. The cranial nerves I, II, V, VII and VIII are affected in the patients reported by Katoch et $a .^{2}{ }^{2}$ Involvement of the first and eighth cranial nerves has also been reported. ${ }^{1,3-6}$

Paralysis of the palate is unusual in leprosy. Its occurrence in association during a Type 2 reaction is of interest, especially as the severity of nerve involvement is usually greater in Type 1 reactions. Masashi and Schigenobu ${ }^{8}$ reported bulbar palsy syndrome of leprosy in 6 patients with involvement of cranial nerves VII, IX, X and XI. They suggest an immunological mechanism as an aetiological factor. The most severe focus of inflammation was found in the nucleus ambiguus. ${ }^{9}$ Leprous granulomata may occur in the palate in lepromatous patients. ${ }^{10}$ The motor fibres derived from the nucleus ambiguus are distributed through the glossopharyngeal, vagus and cranial accessary nerves to the striated muscles of the palate, pharynx and larynx. With the exception of tensor palati, which is innervated by the mandibular division of the trigeminal nerve, muscles of the palate are supplied by fibres of the cranial part of the eleventh nerve which run in the vagus. ${ }^{11}$ The normal CSF and isolated palatal palsy unassociated with 
Table 1. Summary of the clinical features, laboratory findings, therapy and outcome

\begin{tabular}{|c|c|c|c|c|}
\hline Date & Clinical features & Laboratory findings & Therapy & Outcome \\
\hline 3.3 .83 & $\begin{array}{l}\text { Bilateral symmetrical } \\
\text { multiple, shiny, } \\
\text { ill-defined macules } \\
\text { and plaques on face, } \\
\text { trunk and limbs. }\end{array}$ & $\begin{array}{l}\text { Slit-skin smears AFB. } \\
\text { BI } 6+, \text { MI } 68 \% \text {. Skin } \\
\text { biopsy features typical } \\
\text { of LL leprosy. Routine } \\
\text { blood and urine tests } \\
\text { within normal limits. }\end{array}$ & $\begin{array}{l}\text { Tab. dapsone } 100 \mathrm{mg} \\
\text { daily till } 5.6 .86 .\end{array}$ & $\begin{array}{l}\text { Gradual clinical } \\
\text { improvement with } \\
\text { less infiltration of } \\
\text { skin lesions. } \\
\text { Gradual fall in MI } \\
\text { to } 42 \% \text { on } \\
6.6 .86 \text {; BI } 6+.\end{array}$ \\
\hline 6.6 .86 & $\begin{array}{l}\text { Type } 2 \text { reaction } \\
\text { with fever, neuralgia } \\
\text { and ENL lesions. } \\
\text { Right and left ulnar } \\
\text { and common peroneal } \\
\text { nerves thickened and } \\
\text { tender at elbow and } \\
\text { popliteal fossa, } \\
\text { respectively. }\end{array}$ & $\begin{array}{l}\text { Slit-skin smears BI } 6+ \\
\text { MI } 42 \% . \text { ESR } 60 \mathrm{~mm} \\
\text { first hour, Blood TC } \\
12,000 \text { cells/c mm; } \\
\text { VDRL negative, } \\
\text { SGPT } 40 \text { IU/L. } \\
\text { Chest X-ray normal. }\end{array}$ & $\begin{array}{l}\text { Tab. dapsone } 100 \mathrm{mg} \\
\text { daily, Cap. Rif ampicin } \\
600 \mathrm{mg} \text { once a } \\
\text { month, cap clof azimine } \\
100 \mathrm{mg} \text { tid, } \\
\text { Tab Ibuprofen } \\
400 \mathrm{mg} \text { tid till } 23.6 .86 .\end{array}$ & $\begin{array}{l}\text { Type } 2 \text { reaction } \\
\text { persisted till } \\
20.8 .1986 .\end{array}$ \\
\hline 24.6 .88 & $\begin{array}{l}\text { Developed left } \\
\text { lagophthalmos and } \\
\text { obliteration of } \\
\text { nasolabial fold on the } \\
\text { left side. Ulnar clawing } \\
\text { on the left side. }\end{array}$ & ESR $42 \mathrm{~mm} /$ first hour. & $\begin{array}{l}\text { Tab. prednisolone } 40 \mathrm{mg} \\
\text { daily ( } 24.6 .86-24.7 .86, \\
30 \mathrm{mg} \text { daily till } \\
20.8 .86,25 \mathrm{mg} \text { daily till } \\
20.10 .86,20 \mathrm{mg} \text { daily } \\
\text { till } 20.12 .86,15 \mathrm{mg} \text { daily } \\
\text { till } 28.2 .87,10 \mathrm{mg} \text { daily } \\
\text { till } 30.4 .87, \text { then } 5 \mathrm{mg} \\
\text { daily till } 16.7 .87) . \\
\text { Dapsone, rif ampicin and } \\
\text { clofazimine continued. } \\
\text { Clof azimine dose } \\
\text { reduced to } 200 \mathrm{mg} \text { daily } \\
\text { on } 20.10 .86 \text {, and then } \\
100 \text { mg daily } 16.7 .87 \\
\text { onwards. It was further } \\
\text { reduced to } 100 \text { mg on } \\
\text { alternate days from } \\
10.10 .1987 .\end{array}$ & $\begin{array}{l}\text { Gradual regression } \\
\text { of Type } 2 \text { reaction, } \\
\text { steroid withdrawn } \\
\text { on } 16.7 .87 \text {. Persistent } \\
\text { lagophthalmos } \\
\text { and ulnar paralysis, } \\
\text { BI } 6+\text {, MI } 10 \% \text {. } \\
\text { Antileprosy drugs } \\
\text { continued. }\end{array}$ \\
\hline
\end{tabular}

paralysis of the pharynx and larynx in our patient suggest involvement distal to the nucleus ambiguus. Palatal palsy in our patient was probably caused by the bilateral involvement of the peripheral motor fibres that supply the striated muscles of the soft palate. Nasal regurgitation of the food was caused by the failure of the paralysed soft palate to shut off the nasopharynx during swallowing. This might suggest either the involvement of all muscles or that the tensor is too weak to affect sufficient movement. For the same reason his voice acquired a nasal resonance. ${ }^{12}$ This report emphasizes the need to also consider leprosy in the differential diagnoses of palatal palsy. It also stresses the importance of administering corticosteroid at the earliest evidence of palatal palsy, which if unilateral may be completely asymptomatic. Another question is also raised by the persistent ulnar paralysis and foot drop. The possibility of early release or constriction at the cubital tunnel and at the neck of the fibula combined with steroid therapy merits consideration. 
Table 1. Continued

\begin{tabular}{|c|c|c|c|c|}
\hline Date & Clinical features & Laboratory findings & Therapy & Outcome \\
\hline 9.5 .88 & $\begin{array}{l}\text { Recurrence of Type } 2 \\
\text { reaction with ENL } \\
\text { lesions. Developed } \\
\text { foot drop left side, } \\
\text { nasal regurgitation } \\
\text { of food and nasal } \\
\text { resonance of voice. } \\
\text { Complete palatal } \\
\text { paralysis, with } \\
\text { absent reflex. } \\
\text { Pharyngeal reflex } \\
\text { retained. Normal } \\
\text { palatal sensations. }\end{array}$ & $\begin{array}{l}\text { Slit-skin smears BI } 5+ \\
\text { MI } 4 \% \text {. CSF-cells, } \\
\text { proteins within normal } \\
\text { limits. Blood sugar } \\
\text { fasting } 80 \mathrm{mg} \% \text {. }\end{array}$ & $\begin{array}{l}\text { Tab. prednisolone } 80 \mathrm{mg} \\
\text { daily for } 1 \text { month, } \\
60 \mathrm{mg} \text { daily for } 1 \text { month, } \\
40 \mathrm{mg} \text { daily for } 1 \text { month, } \\
30 \mathrm{mg} \text { daily for } 1 \text { month, } \\
20 \mathrm{mg} \text { daily for } 1 \text { month, } \\
15 \mathrm{mg} \text { daily for } 1 \text { month, } \\
10 \mathrm{mg} \text { daily for } 2 \text { months, } \\
5 \mathrm{mg} \text { daily for } 2 \text { months } \\
\text { and stopped on } 7.3 .89 . \\
\text { Dapsone, rif ampicin and } \\
\text { clof azimine continued. } \\
\text { Dose of clofazimine } \\
300 \mathrm{mg} \text { daily for } 3 \text { months, } \\
\text { then } 200 \text { mg daily for } \\
3 \text { months, then } 100 \mathrm{mg} \\
\text { daily till } 7.3 .89 . \text { Then } \\
100 \text { mg alternate days. }\end{array}$ & $\begin{array}{l}\text { Complete recovery } \\
\text { from palatal palsy } \\
\text { when seen on } 7.3 .89 \text {. } \\
\text { Foot drop, claw hand } \\
\text { and lagophthalmos } \\
\text { unchanged. }\end{array}$ \\
\hline 7.3 .89 & $\begin{array}{l}\text { Skin lesions, regressed } \\
\text { leaving atrophic } \\
\text { macules. Foot drop, } \\
\text { lagophthalmos and } \\
\text { claw hand persist. }\end{array}$ & $\begin{array}{l}\text { Slit-skin smears AFB } \\
\text { 2+MI.O. Histology } \\
\text { of the sural nerve; } \\
\text { thickened perineurium, } \\
\text { nerve parenchyma } \\
\text { replaced by fibrosis } \\
\text { and hyaline } \\
\text { degeneration. Many } \\
\text { granular AFB in } \\
\text { Schwaan cells and } \\
\text { perineurial cells. No } \\
\text { granuloma or amyloid. } \\
\text { Skin biopsy. No } \\
\text { granuloma. Fibrosis } \\
\text { and scanty } \\
\text { lymphocytic infiltration } \\
\text { in dermis. }\end{array}$ & $\begin{array}{l}\text { Dapsone } 100 \mathrm{mg} \text { daily } \\
\text { rifampicin } 600 \mathrm{mg} \text { once a } \\
\text { month, clof azimine } 100 \mathrm{mg} \\
\text { alternate days }+300 \mathrm{mg} \\
\text { once a month }{ }^{7} \text { till } 10.10 .89 \\
\text { when the slit-skin smears } \\
\text { were negative. }\end{array}$ & $\begin{array}{l}\text { Antileprosy drugs } \\
\text { stopped on } 10.10 .89 \text {. } \\
\text { Lagophthalmos, foot } \\
\text { drop and claw hand } \\
\text { persist. Patient is on } \\
\text { follow up. No relapse } \\
\text { of the disease. }\end{array}$ \\
\hline
\end{tabular}

\section{Acknowledgment}

I wish to thank Dr A. Vijayalekshmy, Professor of Pathology, Medical College, Kottayam, for the histopathological evaluation of the biopsies of the skin and nerve.

\section{References}

${ }^{1}$ El Arini F, Shehata MA, Abdel Zeid SA. Eighth cranial nerve affection in leprosy. Int J Lepr, 1970; 38: 164-9.

${ }^{2}$ Katoch K, Ramu G, Sengupta U, Bharadwaj VP. Central nervous system involvement in leprosy. Ind $J$ Lepr, 1984; 56: 813-8.

3 Singh TR, Agarwal SK, Bajaj AK, Singh RK, Singh MM. Evaluation of audiovestibular studies in leprosy. Ind J Lepr, 1984; 56: 24-9.

${ }^{4}$ Chaturvedi VN, Rathi SS, Raizda RM, Jain SK. Olfaction in leprosy. Ind J Lepr, 1985; 57: 814-19. 
${ }^{5}$ Mann SBS, Kumar B, Yande R, Kaur S, Kaur I, Mehra YN. Eighth nerve evaluation in leprosy. Ind J Lepr, 1987; 59: 20-5.

${ }^{6}$ Awasthi SK, Singh G, Dutta RK, Pahuja OP. Audiovestibular involvement in leprosy. Ind J Lepr, 1990; 62: 429-34.

${ }^{7}$ WHO Study Group. Chemotherapy of Leprosy for Control Programmes. WHO Technical Report Series No. 675, WHO, Geneva, 1982.

${ }^{8}$ Masashi N, Schigenobu K. Bulbar palsy syndrome of leprosy due to cranial nerve involvement and its suppression. Abstracts of Twelf th Joint Leprosy Research Conference, Boston, 1977. Int J Lepr, 1978; 46: $120-21$.

${ }^{9}$ Norisuka S, Masashi N. Histopathological studies on leprotic bulbar palsy. Abstracts of Eighth Joint Leprosy Research Conference, San Fransisco, 1973. Int J Lepr, 1974; 42: 123.

${ }^{10}$ Kumar B, Yande R, Kaur I, Mann SBS, Kaur S. Involvement of the palate and cheek in leprosy. Ind J Lepr, 1988; 60: $280-4$.

11 Williams PL, Warwick R, Dyson M and Bannister HL, eds. Gray's Anatomy, 37th edition. Churchill Livingstone, Edinburgh, London, Melbourne and New York, 1989; p. 1290.

12 Bannister R. Brain's Clinical Neurology, 4th edition. The English Language Book Society and Oxford University Press, London, 1973; p. 61. 